\title{
Clinicopathological effects of pepper (oleoresin capsicum) spray
}

\author{
MF Yeung *, William YM Tang
}

\section{A B S T R A C T}

Objectives: Pepper (oleoresin capsicum) spray is one of the most common riot-control measures used today. Although not lethal, exposure of pepper spray can cause injury to different organ systems. This review aimed to summarise the major clinicopathological effects of pepper spray in humans.

Data sources: MEDLINE, EMBASE database, and Cochrane Database of Systematic Reviews were used to search for terms associated with the clinicopathological effects of pepper spray in humans and those describing the pathophysiology of capsaicin. A phone interview with two individuals recently exposed to pepper spray was also conducted to establish clinical symptoms.

Study selection: Major key words used for the MEDLINE search were "pepper spray", "OC spray", "oleoresin capsicum"; and other key words as "riot control agents", "capsaicin", and "capsaicinoid". We then combined the key words "capsaicin" and "capsaicinoid" with the major key words to narrow down the number of articles. A search with other databases including EMBASE and Cochrane Database of Systematic Reviews was also conducted with the above phrases to identify any additional related articles.

Data extraction: All article searches were confined to human study. The bibliography of articles was screened for additional relevant studies including non-indexed reports, and information from these was also recorded. Non-English articles were included in the search.
Data synthesis: Fifteen articles were considered relevant. Oleoresin capsicum causes almost instantaneous irritative symptoms to the skin, eyes, and respiratory system. Dermatological effects include a burning sensation, erythema, and hyperalgesia. Ophthalmic effects involve blepharospasm, conjunctivitis, peri-orbital oedema, and corneal pathology. Following inhalation, a stinging or burning sensation can be felt in the nose with sore throat, chest tightness, or dyspnoea. The major pathophysiology is neurogenic inflammation caused by capsaicinoid in the pepper spray. There is no antidote for oleoresin capsicum. Treatment consists of thorough decontamination, symptomdirected supportive measures, and early detection and treatment of systemic toxicity. Decontamination should be carefully carried out to avoid contamination of the surrounding skin and clothing.

Conclusion: Pepper (oleoresin capsicum) spray is an effective riot-control agent and does not cause life-threatening clinical effects in the majority of exposed individuals. Early decontamination minimises the irritant effects.

\section{Hong Kong Med J 2015;21:542-52 \\ DOI: $10.12809 / \mathrm{hkmj} 154691$}

${ }^{1}$ MF Yeung *, MB, ChB, MRCP (UK)

WYM Tang, FRCP (Edin), FHKAM (Medicine)

${ }^{1}$ Department of Medicine and Geriatrics, Tuen Mun Hospital, Tuen Mun, Hong Kong

2 Private practice, Hong Kong

* Corresponding author: wmfyeung@hotmail.com; yeungmf1@ha.org.hk

\section{Introduction}

Pepper spray has been commonly employed for decades by government agencies or military forces worldwide as a non-lethal incapacitating agent against interpersonal violence or civil unrest, and for law enforcement, criminal incapacitation, personal self-defence, and sometimes control of wild animals. It was first used by Federal Bureau of Investigation personnel in the US in 1973. It is usually used when someone is under threat and wants to defend himself from an attacker. It is also known as a riot-control agent or harassing agent. Pepper spray is also used by the Hong Kong Police Force. In this article, the related clinicopathological effects of pepper spray are discussed with a review of the medical literature.

\section{Chemistry of oleoresin capsicum}

The active ingredient in pepper spray is oleoresin capsicum (OC), an oily concentrated extract from pepper plants of the genus Capsicum, commonly referred as chilli pepper (Capsicum annuиm). For centuries, people have used pepper extracts to prepare spicy foods. Other uses include neurobiological research, local anaesthesia, and the production of self-defence products. Oleoresin capsicum comprises a group of fat-soluble pungent chemical phenols described as 'capsaicinoids'. There are five naturally occurring capsaicinoids: 
capsaicin, dihydrocapsaicin, nordihydrocapsaicin, homocapsaicin, and homodihydrocapsaicin. The most pungent capsaicinoid analogues are capsaicin (trans-8-methyl-N-vanillyl-6-nonenamide, $\mathrm{C}_{18} \mathrm{H}_{27} \mathrm{NO}_{3}$ with molecular weight of 305.4) and dihydrocapsaicin: together they constitute 80\% to $90 \%$ of the total concentration in pepper spray products. ${ }^{1,2}$ The absolute and relative abundance of each capsaicinoid analogue varies in fresh peppers and OC spray products. Nonivamide, or 'synthetic' capsaicin, exhibits the same pungency as capsaicin. ${ }^{3}$

\section{Methods}

A literature review was conducted using the MEDLINE database (from 1946 to present), and major key words of "pepper spray", "OC spray", "oleoresin capsicum" and other key words of "riot control agents", "capsaicin", and "capsaicinoid". We then combined the key words "capsaicin" and "capsaicinoid" with the major key words to narrow down the number of articles. All article searches were limited to human study. Search with other databases including EMBASE and Cochrane Database of Systematic Reviews was also conducted with the above phrases to look for any additional related articles. The bibliography of relevant articles was screened for additional relevant studies including non-indexed reports. Non-English articles were included in the search. Phone interview was conducted with individuals recently exposed to pepper spray in Hong Kong to obtain information about exposure history and symptomatology.

\section{Results}

A total of 111 articles were identified of which 15 were considered relevant to our review. The details are summarised in Table $11^{4-18}$ Our search identified 10 studies published formally in peer-reviewed medical and scientific journals that addressed the clinicopathological effects of OC spray in humans. The remaining five papers were case reports of the clinical effects of OC spray on a particular organ system.

One of the authors (MF Yeung) conducted a telephone interview with two pepper spray victims. One 22-year-old man sustained direct lateral spray to his neck and forearm from a distance of 1 to $2 \mathrm{~m}$. $\mathrm{He}$ experienced an almost immediate burning sensation over the sprayed areas, described as a very strong mint feeling. He then flushed himself with water but the chemical contaminated his clothes and other skin areas resulting in persistent burning pain for 30 minutes. Pain gradually resolved after an hour. Another 29-year-old woman sustained spray to her arm and forearm from a distance of approximately $5 \mathrm{~m}$. Immediately she experienced a severe burning sensation over the affected areas (Fig 1), described

\section{胡椒（辣椒油樹脂）噴霧的臨床病理特徵 楊明晃、鄧旭明}

目的：胡椒（辣椒油樹脂）噴霧是現時其中一種最常用的防暴措施。 雖不會致命, 但接觸胡椒噴霧可能會對不同的器官或系統造成損害。 本文旨在總結胡椒噴霧對於人體可能造成的主要臨床病理特徵。

資料來源：根據MEDLINE、EMBASE數據庫和Cochrane系統評價數 據庫搜集有關胡椒噴霧導致人體各臨床病理特徵的研究, 以及那些描 述辣椒素所帶來病理生理學影響的文章, 另外以電話訪問兩名被施以 胡椒噴霧人士的臨床症狀。

研究選取：用於MEDLINE搜索的主要關鍵詞為「胡椒噴霧」 （pepper spray）、「OC噴霧」（OC spray）和「辣椒油樹脂」 (oleoresin capsicum)；其餘關鍵詞為「控暴劑」（riot control a gents ）、「辣椒素」（capsaicin）和「辣椒素類物質」 （capsaicinoid）。然後, 結合「辣椒素」（capsaicin）和「辣椒素類 物質」（capsaicinoid）作為關鍵詞來縮減文章數量, 再利用相同的關 鍵詞搜索其他數據庫, 包括EMBASE數據庫和Cochrane系統評價數 據庫來尋找額外的相關文章。

資料提取：所有文章搜索僅限於對人體方面的研究，也透過文章內的 參考文獻搜尋其他相關文章，包括記錄一些未被收錄的報告的內容。 搜索中也包含非英語文章。

資料綜合：共有十五篇相關文章被納入研究範圍。辣椒油樹脂會對皮 膚、眼睛和呼吸系統引致幾乎瞬間的刺激症狀。對皮膚造成的影響包 括燒灼感、出現紅斑和痛覺過敏。對眼部造成的影響包括眼瞼痙攣、 結膜炎、眶周水腫和角膜病變。辣椒油樹脂被吸入人體後, 鼻子會有 刺痛或燒灼感, 還有咽痛、胸悶和呼吸困難。最主要的病理生理反應 是由胡椒噴霧中的辣椒素所造成的神經源性炎症。辣椒油樹脂並沒有 解藥。治療包括徹底清洗、針對出現症狀的措施, 以及及早發現和治 療系統性毒性。應小心清洗受影響部位以免周圍的皮膚和衣服受到污 染。

結論：胡椒（辣椒油樹脂）噴霧是一種有效的防暴劑，對於大部分人 來説它不會危害生命。盡快清洗受影響部位能減少辣椒油樹脂引起的 刺激作用。

as touching chilli seeds. She irrigated herself with water in the public toilet. The upper chest was also involved due to contamination of her clothing. Following irrigation, pain reduced over the next few hours to a mild hot sensation but still continued. She took a bath with warm water and baby shampoo 3 hours after exposure but experienced increased pain over the sprayed area. The pain resolved completely around 5 hours post-exposure.

\section{Clinical features}

Exposure to $\mathrm{OC}$ can be via direct contact with skin, eyes or mucous membranes, or as a result of inhalation or ingestion. The irritant effects result in almost instantaneous onset of symptoms: within seconds it can induce a burning sensation on skin, involuntary closure of eyes, and diminished 
TABLE I. Clinical presentation and site exposure with oleoresin capsicum spray ${ }^{4-18}$

\begin{tabular}{|c|c|c|c|c|c|c|}
\hline \multirow[b]{3}{*}{ Study period (year) } & \multicolumn{6}{|c|}{ Case series } \\
\hline & \multirow{2}{*}{$\begin{array}{c}\text { Stopford, } \\
\text { 2004 }\end{array}$} & \multirow{2}{*}{$\begin{array}{c}\text { Kearney et al, } \\
\mathbf{2 0 1 4}\end{array}$} & \multicolumn{2}{|c|}{ Forrester and Stanley, ${ }^{7} 2003$} & \multirow{2}{*}{$\begin{array}{c}\text { Watson et al, }^{5} \\
\mathbf{1 9 9 6} \\
1991-1994\end{array}$} & \multirow{2}{*}{$\begin{array}{c}\text { Brown et al, }{ }^{10} \\
\mathbf{2 0 0 0}\end{array}$} \\
\hline & & & 1998-2002 & $2000-2002$ & & \\
\hline No. of persons exposed & 6000 & 3671 & 1531 & 762 & 908 & 100 \\
\hline Male / female & NR & $\begin{array}{c}1882 / 1722 \\
\text { (67 Unknown) }\end{array}$ & $\begin{array}{c}864 \text { / } 625 \\
\text { (42 Unknown) }\end{array}$ & NR & NR & $87 / 13$ \\
\hline Age range (mean) in years & NR & $23-24$ & NR & NR & $(27.6)$ & $\begin{array}{l}\text { M: } 17-56(31.8) \\
\text { F: } 19-54(36.8)\end{array}$ \\
\hline OC concentration (\%) & NR & NR & NR & NR & 5 & 10 \\
\hline OC (SHU, million) & NR & NR & NR & NR & NR & NR \\
\hline No. of persons requiring treatment & $61(1 \%)$ & NR & NR & NR & $81(9 \%)$ & NR \\
\hline \multicolumn{7}{|l|}{ Symptoms, No. (\%) of victims* } \\
\hline Dermatological & $5(8+)$ & $2183(59.5 \ddagger)$ & $821(53.6 \ddagger)$ & NR & $26(32.1 \dagger)$ & NR \\
\hline Burning sensation & NR & NR & NR & $337(44.2)$ & $20(24.7)$ & NR \\
\hline Erythema & NR & NR & NR & $125(16.4)$ & $12(14.8)$ & NR \\
\hline Erythema with blister & NR & $44(1.2)$ & NR & NR & NR & NR \\
\hline Ocular & $28(46 \dagger)$ & $1913(52.1 \ddagger)$ & 595 (38.9‡) & NR & $63(77.8 \dagger)$ & NR \\
\hline Burning sensation & $\mathrm{NR}$ & NR & NR & $290(38.1)$ & $45(55.6)$ & NR \\
\hline Lacrimation & NR & NR & NR & $70(9.2)$ & $13(16.0)$ & NR \\
\hline Blepharospasm & NR & NR & NR & NR & NR & NR \\
\hline Conjunctival injection & NR & NR & NR & $90(11.8)$ & $36(44.4)$ & $38(38.0)$ \\
\hline Conjunctival proliferation & NR & NR & NR & NR & NR & NR \\
\hline Corneal abrasion/erosion/ulcer & NR & $134(3.6)$ & NR & NR & $7(8.6)$ & $7(7.0)$ \\
\hline Respiratory & $20(33 \dagger)$ & 754 (20.5‡) & $336(21.9 \ddagger)$ & NR & $6(7.4 \dagger)$ & NR \\
\hline Cough & $\mathrm{NR}$ & NR & NR & $75(9.8)$ & $1(1.2)$ & NR \\
\hline Shortness of breath & NR & $79(2.1)$ & NR & NR & $3(3.7)$ & NR \\
\hline Wheezing & NR & $10(0.3)$ & NR & NR & $2(2.5)$ & NR \\
\hline Oral/throat irritation & NR & NR & NR & $72(9.4)$ & $1(1.2)$ & NR \\
\hline
\end{tabular}

Abbreviations: $\mathrm{NR}=$ not reported or not applicable; $\mathrm{OC}=$ oleoresin capsicum; $\mathrm{SHU}=$ Scoville heat units

* Total $>100 \%$ as patients could have more than one exposure route and more than one clinical symptom

$\dagger$ The denominator was based on the number of victims requiring treatment

¥ The denominator was based on the number of victims exposed to pepper spray

hand-eye coordination. Victims are usually rapidly incapacitated although most symptoms resolve within 30 to 60 minutes. The use of pepper spray by the US police has been reported to be successful in subduing aggressive individuals in $90 \%$ of cases. ${ }^{19}$

\section{Dermatological injury}

Initial contact of capsaicin with skin or mucous membranes produces a violent irritation with subsequent desensitisation to irritant chemicals. Victims experience acute burning pain, tingling, erythema, oedema, and pruritus (the pain can be prolonged for several hours in persons not adequately decontaminated). ${ }^{4,20}$ In prolonged exposure and in severe cases, persistent dermatitis with severe erythema and/or blister formation may occur. ${ }^{4,20}$

Kearney et $\mathrm{al}^{4}$ made a retrospective chart review of all human exposures to pepper spray recorded in the electronic database of the California Poison Control System during 2002-2011 (Table 1). Of the 3671 victims recorded, the most common type of exposure was dermal (2183 victims, 59.5\%) with $2080(56.7 \%)$ victims reporting minor/selflimiting symptoms, and 103 (2.8\%) reporting more severe symptoms that required medical evaluation, including persistent dermatitis, dermal burns, and/ or blister formation.

Watson et $\mathrm{al}^{5}$ conducted a retrospective study based on medical record review of 81 patients who presented to an emergency department after exposure to OC (908 individuals in total exposed during law enforcement) in 1991 to 1994 in Kansas City, Missouri, US. In 26 (32.1\%) cases the chief symptoms upon arrival to casualty were pain or 


\begin{tabular}{|c|c|c|c|c|c|c|c|c|c|}
\hline \multicolumn{5}{|c|}{ Case series } & \multicolumn{5}{|c|}{ Case reports } \\
\hline $\begin{array}{c}\text { Zollman et } \\
\text { al, }{ }^{8} 2000\end{array}$ & $\begin{array}{c}\text { Oh et al, }{ }^{13} \\
2010\end{array}$ & $\begin{array}{c}\text { Lee et al, }{ }^{12} \\
1996\end{array}$ & $\begin{array}{l}\text { Vesaluoma } \\
\text { et al, }{ }^{11} 2000\end{array}$ & $\begin{array}{c}\text { Brvar, }^{14} \\
2013\end{array}$ & $\begin{array}{l}\text { Holopainen } \\
\text { et al, }{ }^{15} 2003\end{array}$ & $\begin{array}{c}\text { Kniestedt et } \\
\text { al, }^{16} 2005\end{array}$ & $\begin{array}{c}\text { Shimada et } \\
\text { al, }{ }^{17} 2012\end{array}$ & $\begin{array}{l}\text { Gerber et } \\
\text { al, }{ }^{9} 2011\end{array}$ & $\begin{array}{c}\text { Das et al, }{ }^{18} \\
2005\end{array}$ \\
\hline NR & 2008 & NR & NR & 2012 & - & - & - & - & - \\
\hline 47 & 13 & 13 & 10 & 15 & 4 & 2 & 1 & 1 & 1 \\
\hline $35 / 12$ & $5 / 8$ & NR & $9 / 1$ & NR & - & - & - & - & - \\
\hline $21-47$ & $14-56$ & NR & NR & (34) & $(27)$ & - & 21 & 2.5 & 75 \\
\hline NR & NR & 5 & 5.5 & NR & 5 & 2.6 & - & 10 & - \\
\hline $0.5-1$ & NR & NR & NR & NR & - & - & - & - & - \\
\hline NR & 13 & 13 & 10 & 15 & 4 & - & - & - & - \\
\hline $47(100)$ & $2(15)$ & NR & $10(100)$ & NR & - & - & - & - & - \\
\hline NR & NR & NR & $10(100)$ & $15(100)$ & - & - & - & - & - \\
\hline 47 (100) & NR & NR & $10(100)$ & $12(80)$ & - & - & - & - & - \\
\hline NR & NR & NR & NR & NR & - & - & - & - & - \\
\hline 47 (100) & $9(69)$ & $13(100)$ & $10(100)$ & NR & - & - & - & - & - \\
\hline 47 (100) & NR & 13 (100) & $10(100)$ & NR & - & - & 1 & 1 & - \\
\hline 47 (100) & NR & NR & NR & $8(53)$ & - & - & - & - & - \\
\hline 47 (100) & NR & $13(100)$ & NR & $5(33)$ & - & - & - & - & - \\
\hline 47 (100) & NR & $13(100)$ & $10(100)$ & $2(13)$ & 3 & - & 1 & 1 & - \\
\hline NR & NR & NR & NR & NR & - & - & - & 1 & - \\
\hline NR & NR & NR & $4(40)$ & NR & 4 & 2 & 1 & - & 1 \\
\hline NR & NR & $13(100)$ & NR & NR & - & - & - & - & - \\
\hline NR & $4(31)$ & NR & NR & NR & - & - & - & - & - \\
\hline NR & $2(15)$ & NR & NR & NR & - & - & - & - & - \\
\hline NR & NR & NR & NR & NR & - & - & - & - & - \\
\hline NR & $8(62)$ & NR & NR & NR & - & - & - & - & - \\
\hline
\end{tabular}

a burning sensation in exposed skin. In the US, a retrospective case review of approximately 6000 officers was conducted at the Department of Corrections; these officers were exposed to pepper spray during training in 1993 to $19955^{6,21}$ Only 61 (1\%) required medical treatment: five (8\%) complained of dermatological symptoms of whom two had hives. Forrester and Stanley ${ }^{7}$ used data derived from telephone calls to the Texas Poison Center Network to investigate the epidemiology of $\mathrm{OC}$ exposure. Of 762 human exposures during 2000 to 2002, 337 (44.2\%) experienced dermal irritation/pain and 125 (16.4\%) had erythema on exposed skin.

\section{Ophthalmic injury}

Contact of the eye with OC causes redness, swelling, severe burning pain, tingling, lacrimation, and involuntary or reflex closing of the eyelids. More severe symptoms include persistent pain, foreign body sensation, photophobia, discharge or exudate, or peri-orbital oedema. Zollman et $\mathrm{al}^{8}$ showed that in police cadet volunteers sprayed in the face with OC, the most significant symptoms were conjunctival and scleral irritation and blepharospasm. Symptoms usually resolved within 1.5 to 2 hours of decontamination although mild chemosis, corneal oedema, or hyphaema could persist.

Conjunctival proliferation has been reported in a young child following mild spray injury and was refractory to steroid therapy with subsequent need for surgical excision. ${ }^{9}$ Decreased tear production as evidenced by a lower Schirmer test score was found. An impaired corneal reflex lacrimation and corneal blink reflex have also been observed. ${ }^{22}$ 


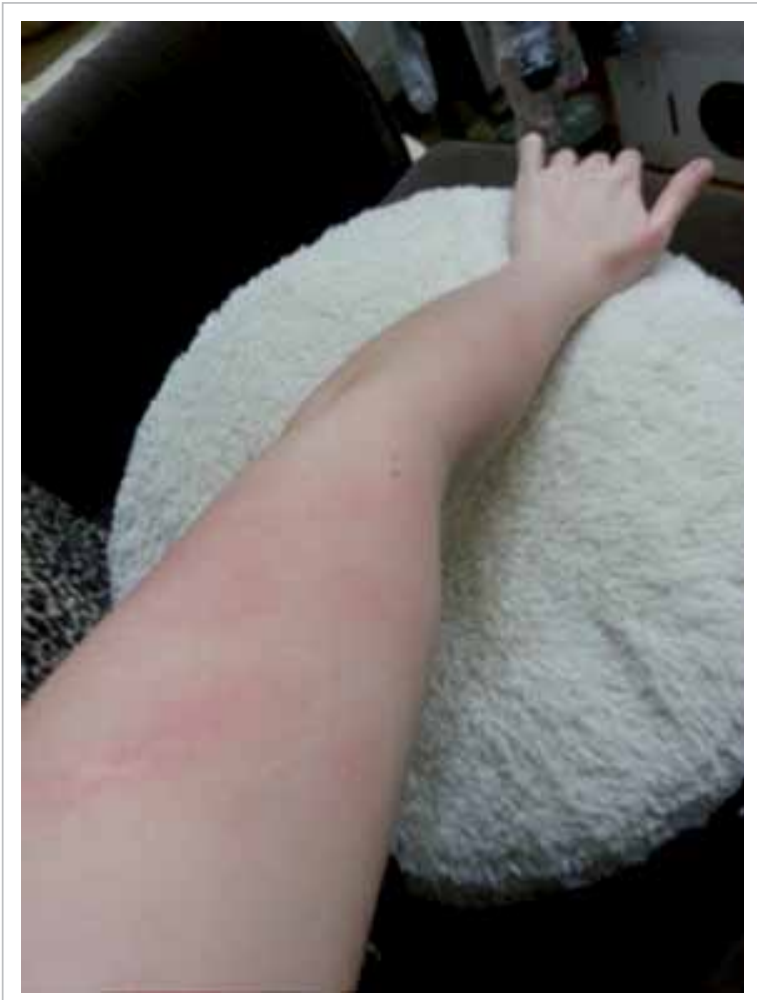

FIG I. Dermatitis in the affected area 4 hours following exposure

(Reproduced with permission of Miss YYTse)

Oleoresin capsicum spray can affect both morphology and sensitivity of the cornea. Brown et $\mathrm{al}^{10}$ demonstrated that of 100 exposed individuals (10\% OC spray), $7 \%(n=7)$ had corneal abrasion. Watson et a $l^{5}$ found $8.6 \%(n=7)$ of 81 affected officers who required medical treatment actually had corneal abrasion. Epstein and Majmudar ${ }^{23}$ described a case with keratopathy, and the victim's eye showed a corneal epithelial defect after OC spray to the eyes. Although the defects healed within 5 days of treatment with polymyxin-bacitracin ophthalmic ointment, smouldering inflammation persisted. Further treatment with tobramycin-dexamethasone drops every 4 hours caused the inflammation to subside but superficial stromal opacity remained, resulting in irregular astigmatism. ${ }^{23}$

Zollman et $\mathrm{al}^{8}$ demonstrated that corneal sensation was severely affected after 10 minutes and 1 hour of exposure. At 1 week, sensation returned to baseline and corneal abnormalities disappeared. Apart from capsaicin, the carrier vehicle in which the active ingredient is dissolved may be toxic to corneal epithelial cells and cause temporary ocular irritation or superficial keratitis or erosion. ${ }^{12}$

\section{Oral, nasal, and respiratory toxicity}

Exposure may occur through inhalation, causing immediate inflammation of mucous membranes. Throat irritation results in a burning sensation, cough, choking, and inability to speak (due to laryngospasm or laryngeal paralysis). In the nasal mucosa, OC produces irritation, burning pain, sneezing, and a dose-dependent serous discharge. ${ }^{24}$ Other respiratory symptoms have also been reported, including severe coughing, mucus secretion, shortness of breath, bronchoconstriction presenting as wheeze, and chest tightness. Direct contact of capsaicinoids with the vocal cords causes laryngospasm lasting 45 seconds. ${ }^{21}$ Duration or magnitude of bronchoconstriction did not differ among normal subjects, smokers, and asthmatics. ${ }^{21}$

A review by Watson et $\mathrm{al}^{5}$ of 81 victims of law enforcement action revealed that $7.4 \%(n=6)$ had respiratory symptoms after inhalation of OC spray, and $3.7 \%(n=3)$ complained of shortness of breath. Oh et $\mathrm{al}^{13}$ studied an incident of OC gas leak in an urban shopping mall that affected 13 victims, of whom two (15\%) experienced shortness of breath and eight (62\%) complained of oral/throat irritation.

A controlled clinical trial involving 35 healthy subjects exposed to OC spray did not detect significant changes in predicted forced expiratory volume in 1 second $\left(\mathrm{FEV}_{1}\right)$ or oxygen saturation when compared with population norms. ${ }^{25}$ The prone maximum restraint position reduced forced vital capacity $(\mathrm{FVC})$ and $\mathrm{FEV}_{1}$ by $15 \%$ compared with a sitting position, but there was no statistically significant difference in these parameters when use of $\mathrm{OC}$ and controls were compared in the restraint position. ${ }^{25}$

\section{Systemic toxicity and death}

Inhalation of OC spray can cause laryngeal and pulmonary oedema and chemical pneumonitis but this is rare. ${ }^{21}$ An 11-year-old child who directly inhaled a jet spray from a pressurised container ultimately recovered but was reported to develop subglottic obstruction of the trachea and bilateral pulmonary infiltration that required intubation. ${ }^{26}$ Billmire et $\mathrm{al}^{27}$ described a 4-week-old healthy infant exposed to $5 \%$ OC when a self-defence device was accidentally discharged; the infant developed respiratory failure and hypoxaemia requiring extracorporeal membrane oxygenation. The patient was discharged and 12-month follow-up revealed several episodes of viral respiratory infections. ${ }^{27}$

Some studies have reported systemic symptoms including disorientation, fear, loss of body motor control (eg diminished hand-eye coordination), ${ }^{28}$ hyperventilation, tachycardia, and pulmonary oedema. ${ }^{21}$ The acute increase in blood pressure could cause headache, increased stroke risk and heart attack. ${ }^{21}$ In a review of approximately 6000 (police) officers directly exposed to OC, eight $(0.1 \%)$ trainees reported headache and chest problems that 
persisted for more than 1 week. $^{6}$

Since 1993, over 70 in-custody deaths have involved the use of $\mathrm{OC}$ spray during the arrest process. ${ }^{29}$ At the same time, Amnesty International has claimed that since the early 1990 s more than 100 people in the US have died following exposure to pepper spray. ${ }^{30}$ Steffee et al $^{31}$ reported an in-custody death in a known asthmatic who had been sprayed 10 to 15 times with OC spray (Table 2). O'Halloran and Frank $^{29}$ reported 21 cases of restraint incustody death, of which 10 were preceded by use of OC spray. Granfield et $\mathrm{al}^{32}$ reported 30 cases of in-custody death following OC exposure in the US but this review concluded that pepper spray was not the cause of death in any of the cases. Pollanen et $\mathrm{al}^{33}$ reported 21 in-custody restraint deaths in which four of the subjects had been sprayed with OC. Details are shown in Table 3..$^{29,31-33}$

\section{Decontamination}

The pre-hospital management of an individual exposed to pepper spray should include prompt onscene removal of exposure to reduce the source of

TABLE 2. Relative "heat" of edible peppers and capsaicin"

\begin{tabular}{lc}
\hline Source & Scoville heat units (HPLC) \\
\hline Jalapeño pepper & 5000 \\
Cayenne pepper & $2500-25000$ \\
Habanero pepper & $85000-200000$ \\
Pure capsaicin & 15000000 \\
Oleoresin capsicum (10\%) & 1500000 \\
\hline
\end{tabular}

Abbreviation: HPLC = high-performance liquid chromatography irritation. First, victims should move away from any continuing source of exposure. The presence of any signs or symptoms of serious systemic distress such as cardiovascular or respiratory problems should be ascertained. ${ }^{13}$ The immediate and most readily available method of decontamination at the scene of exposure is likely to be water. The affected skin and mucous membranes should be irrigated thoroughly with copious amounts of cool water to help soothe the burning sensation and flush away any spray residue. $^{12}$

Some authors suggest that eyes exposed to OC should be irrigated with copious amounts of roomtemperature water or normal saline for at least 15 minutes. ${ }^{4}$ If the victim is wearing contact lenses, they should be removed as quickly as possible. ${ }^{12}$ Washing the eyelids with a mild, oil-free soap will help break down the OC resin and speed up its removal. ${ }^{12}$ If a high level of spray residue is present in clothing, it should be removed and placed in sealed plastic bags until it can be cleaned or discarded..$^{12}$ Removal of contaminated clothing will aid in preventing secondary contamination. Contamination by used towels should be avoided. ${ }^{12}$ Showering with soap and water is advised to remove the irritant from skin that should be blotted dry, not rubbed. ${ }^{12}$

For acute relief of burning dermal pain, one study suggested application of magnesiumaluminium hydroxide suspension. ${ }^{34}$ Vegetable oil immersion and vinegar have been reported to be more effective than water in relief of burning sensation. ${ }^{35,36}$ One study of 49 volunteer adult law enforcement trainees exposed to $\mathrm{OC}$ during a routine training exercise, who were randomised to one of five treatment groups (aluminium hydroxidemagnesium hydroxide, $2 \%$ lidocaine gel, baby

TABLE 3. Reported deaths with pepper spray use identified as one of the circumstances surrounding death $\mathrm{h}^{29,31-33}$

\begin{tabular}{|c|c|c|c|c|c|c|c|}
\hline & City and year(s) & $\begin{array}{l}\text { Total } \\
\text { unex- } \\
\text { pected } \\
\text { death }\end{array}$ & $\begin{array}{l}\text { Subdued with } \\
\text { pepper spray }\end{array}$ & $\begin{array}{l}\text { Circumstances } \\
\text { surrounding death }\end{array}$ & Chronic illness & Cause of death & $\begin{array}{l}\text { In relation } \\
\text { to pepper } \\
\text { spray } \\
\text { (conclusion } \\
\text { by authors) }\end{array}$ \\
\hline \multirow[t]{2}{*}{ Steffee et $\mathrm{al}^{31}$} & $\begin{array}{l}\text { North Carolina, } \\
\text { US } 1993\end{array}$ & - & 2 In-custody & $\begin{array}{l}\text { Excited delirium, physical } \\
\text { restraint (handcuffed) }\end{array}$ & $\begin{array}{l}\text { Coronary artery } \\
\text { disease }\end{array}$ & $\begin{array}{l}\text { Atherosclerotic } \\
\text { cardiovascular disease }\end{array}$ & Not related \\
\hline & & & & $\begin{array}{l}\text { Excited delirium (acute } \\
\text { alcohol intoxication), } \\
\text { physical restraint } \\
\text { (handcuffed) in prone } \\
\text { position }\end{array}$ & $\begin{array}{l}\text { Chronic bronchitis, } \\
\text { bronchiolitis }\end{array}$ & $\begin{array}{l}\text { Asphyxia due to } \\
\text { bronchospasm } \\
\text { precipitated by pepper } \\
\text { spray }\end{array}$ & Related \\
\hline Pollanen et $\mathrm{al}^{33}$ & $\begin{array}{l}\text { Ontario, Canada } \\
\text { 1988-1995 }\end{array}$ & 21 & $4(19 \%)$ & $\begin{array}{l}\text { Excited delirium (psychiatric } \\
\text { illness), physical restraint }\end{array}$ & - & - & Unknown \\
\hline Granfield et $\mathrm{al}^{32}$ & US 1990-1993 & 30 & 30 & $\begin{array}{l}\text { Excited delirium (including } \\
\text { drugs or alcohol use) }\end{array}$ & - & $\begin{array}{l}\text { Asphyxia, drug-related } \\
\text { factors or diseases }\end{array}$ & Not related \\
\hline $\begin{array}{l}\text { O'Halloran and } \\
\text { Frank }^{29}\end{array}$ & $\begin{array}{l}\text { California, US } \\
1992-1996\end{array}$ & 21 & 10 In-custody & Delirium/paranoid delusions & $\begin{array}{l}15 \text { Had heart } \\
\text { disease (LVH) }\end{array}$ & $\begin{array}{l}\text { Drug toxicities, } \\
\text { cocaine/restraint }\end{array}$ & Unknown \\
\hline
\end{tabular}

Abbreviation: $\mathrm{LVH}=$ left ventricular hypertrophy 
shampoo, milk, or water), reported no significant difference in pain relief. Time after exposure appeared to be the best predictor for decrease in pain. ${ }^{37}$ Medical treatment for dermatitis may include topical steroids, oral antihistamines, and topical antibiotics.

\section{Discussion}

Pepper sprays are generally regarded as immediately effective and less toxic than other riot-control agents such as chloroacetophenone $(\mathrm{CN})$ and ochlorobenzylidene malononitrile (CS). Both $\mathrm{CN}$ and $\mathrm{CS}$ are effective lacrimating agents with $\mathrm{CN}$ the most lethal. The estimated lethal dose $\left(\mathrm{LCt}_{50}\right)$ of $\mathrm{CN}, \mathrm{CS}$, and $\mathrm{OC}$ is 8500,25000 and $>100000 \mathrm{mg} / \mathrm{min} / \mathrm{m}^{3}$, respectively. ${ }^{38}$

Oleoresin capsicum spray contains the active ingredient capsaicin, which is obtained from chilli pepper. Typically, pepper spray weapons contain a $10 \%$ to $20 \%$ solution of OC. The capsaicinoid content determines the 'hotness' of preparation, commonly referred to as Scoville Heat Unit (SHU; Table 2). The scale is named after its creator, American pharmacist Wilbur Scoville. Sprays used in police work typically fall between 0.5 and 2 million SHUs. ${ }^{8}$ The SHU governs the efficacy and pungency of pepper spray, thus the higher the SHU, the greater the inflammatory effect on skin and mucous membranes. A higher concentration of $\mathrm{OC}$ lengthens the necessary recovery period, thus affecting decontamination. ${ }^{39}$ Greater than 5\% OC might not atomise well into a fine spray (may clog the aerosol spray). ${ }^{40}$ The capsaicin and related capsaicinoid content in most law enforcement OC sprays is between $1.3 \%$ and $2 \%$. Areas of exposure can be dermatological, ocular, inhalational, ingestion or mixed, thus symptoms often involve more than one system. The prevalence of severe symptoms observed in various epidemiological studies varies from $2.7 \%$ to $15 \% .{ }^{4,5,7,10}$

We found dermatological manifestation as the most common symptom in the case series (32\%-100\%), ${ }^{5,8,11}$ although another study reported dermatological symptoms in only $8 \%$ of cadet officers exposed to OC. ${ }^{6}$ The predominant site of exposure will be affected by any protective measures adopted: use of protective goggles or shields will greatly diminish exposure of skin to OC. Circumstances of OC spray use will also affect the predominant sites of exposure and severity of symptoms. Faced with confrontation during a public demonstration, officers will target OC spray at the eyes of protestors to quickly incapacitate them. This will result in a greater degree of both dermatological (face) and ocular exposure. Kearney et $\mathrm{al}^{4}$ analysed the risk factors with the largest independent associations with more severe symptoms among 3671 cases exposed to direct $\mathrm{OC}$ spray designed to incapacitate during law enforcement crowd-control activities.

Multiple exposure of skin or mucous membranes over a period of seconds or minutes exaggerate the inflammatory response. Capsaicin exposure may diminish sensitivity to heat- or chemical-induced pain, and thus increase the risk and severity of dermal burns. Some authors have suggested that capsaicin can powerfully stimulate heat receptors to cause reflex sweating and vasodilatation, and activate hypothalamus-mediated cooling; this may result in an increased risk of hypothermia if victims are decontaminated with cold water on cold days. ${ }^{41,42}$ Further, capsaicin-related cutaneous sensation may be heightened by perspiration, lacrimation, high humidity, and bathing at a warm temperature. ${ }^{43}$

The dermatological effects of capsaicin in OC spray have been further described in some case reports. 'Hunan hand' syndrome describes painful contact dermatitis in people preparing chilli peppers (containing capsaicin) by direct handling, ${ }^{44}$ while Sweet's syndrome has been described following exposure to jalapeño peppers. ${ }^{45}$

Respiratory effects of OC spray involve cough reflex stimulation via capsaicin-sensitive nerves and bronchoconstriction. Although OC spray exposure causes cough and transient increase in airway resistance, experimental studies and clinical case reports show no evidence that patients with bronchial hypersensitivity are any more susceptible to the irritant effects of OC spray than those without. ${ }^{5}$ No cases of occupational asthma due to capsaicin have been reported. ${ }^{21}$ A cross-sectional study of workers exposed to capsaicin detected a statistically significant increase in complaints of cough in capsaicin-exposed workers, although there was no significant difference in $\mathrm{FEV}_{1}$ and FVC between the two groups. ${ }^{46}$ Not all asthmatics are sensitive to the bronchoconstrictive effects of OC spray. ${ }^{21}$

As capsaicinoids are lipophilic and have limited water solubility $(16 \mu \mathrm{g} / \mathrm{mL}),{ }^{47}$ alcohols or other organic solvents are commonly used as a base to facilitate aerosolisation in pepper spray products. Suitable solvents include methylene chloride, isopropanol, propylene glycol, ethanol, and methanol. The solvent enhances capsaicinoid solubility to enable delivery to the intended target tissue. A gaseous propellant (usually nitrogen or carbon dioxide) is incorporated in the spray to discharge the canister contents. ${ }^{1}$ Inhalation of high doses of some of these chemicals may produce adverse cardiac, respiratory, and neurological effects, including arrhythmia. ${ }^{21}$ The health effects of solvent and propellants are beyond the scope of our study, but their potential hazards and effects need to be considered.

Little is known about the long-term effects of pepper spray. Concern has been raised about their mutagenic and carcinogenic effects considering 
the organic solvent content, but the findings of numerous studies are inconclusive. Genotoxic effects have been demonstrated for capsaicin, but usually in cultured cells and at micromolar concentrations. ${ }^{48}$ These levels would not normally be achieved in field use. Some authors suggest that single or incidental relatively low doses of OC spray, as used by the police, will not produce a significant cancer risk. ${ }^{19}$ Nonetheless the long-term risks for those sprayed on multiple occasions are unknown. ${ }^{21}$

In the cases of fatality that we identified, a causal connection between OC spray exposure and death remained controversial. A number of deaths in custody occurred after exposure to pepper spray but the cause was not thoroughly investigated. In a report by Steffee et al, ${ }^{31}$ autopsy findings and toxicology results were analysed alongside pre-mortem chain of events, symptomatology, and degree of natural disease process. One asthmatic victim died because of severe acute bronchospasm, probably precipitated by the use of OC spray. ${ }^{31}$ Another review of various fatalities $^{49}$ found that positional asphyxia (subjects are placed prone, typically handcuffed behind the back, hog-tied, and breathing becomes more difficult), drugs (alcohol intoxication, excited delirium [cocaine-induced], methamphetamine), pre-existing respiratory or cardiovascular disease, obesity and other conditions caused or contributed to almost all deaths. ${ }^{21}$ Exposure to OC spray was not judged to be a precipitating factor in any of these cases. ${ }^{50}$ Some authors have concluded that OC spray is not inherently lethal or dangerous. ${ }^{51}$ From the literature search, most cases of death associated with the use of pepper spray involved other factors and there was no convincing evidence that OC spray was implicated.

Although OC is lipophilic and many substances have been recommended for decontamination, water is easily available and of no harm. In the presence of ocular exposure, it is helpful to irrigate the upper and lower palpebral cul-de-sac because spray residue tends to collect in these locations and becomes entrapped. ${ }^{12}$ In one individual whose eyes were exposed to $\mathrm{OC}$, the best-corrected visual acuity with spectacles did not improve beyond 20/40 after 7 months because of irregular astigmatism associated with persistent corneal opacity. ${ }^{23}$ Therefore prompt ocular irrigation is important to avoid potentially permanent ocular sequelae.

The severity of health effects from pepper spray exposure may be contingent on several product-, dispersal-, and patient-related factors. Various handheld pressurised canisters of OC spray are available and at least three variables affect their overall effectiveness. The first is the type, level of 'hotness', or concentration of pepper spray. Since the concentration of extract in pepper sprays varies (5\%-15\%), the potential risks associated with capsaicinoid exposure may vary up to 30-fold among different brands of OC spray. ${ }^{21}$ Second, the physiochemical properties of the solvent, that is, the vehicle type and its chemical solubility, can influence skin bioavailability. ${ }^{52}$ It increases the effectiveness of spray by improving penetration, removing skin oils, or prolonging contact time. ${ }^{12}$ Lastly, the delivery device or propellant-liquid spray, powder, or aerosolisation-dictates particle size and penetration into mucosal membranes and airways.

The severity of injury also depends on the circumstances of exposure. Direct exposure may be accidental or intentional. ${ }^{4}$ The latter involves a higher-risk situation that might require long $\mathrm{OC}$ application and tactics with consequent higher potential for injury. Concurrent disease and health of victims, varying doses, and distance being sprayed also determine different degrees of toxicity. Environmental conditions (windy, rainy weather), and crowd size and characteristics should also be taken into account when assessing level of exposure. Eyeglasses, sunglasses, and other protective eyewear and clothing can greatly reduce the effectiveness of OC sprays, as can the behaviour of the victim. For example, raising the hands in a defensive measure may block the spray. ${ }^{39}$ This was exemplified by the use of goggles and umbrellas at recent altercations with police reinforcement in Hong Kong.

\section{Neurogenic inflammation}

Capsaicin-induced neurogenic inflammation (Fig $2^{21,53}$ ) is associated with heat allodynia (decreased heat pain threshold), thermal and mechanical hyperalgesia and cold hypoesthesia at the site of challenge. ${ }^{54}$ Neurophysiological study has demonstrated increased contact heat pain and shortened latencies of contact heat-evoked potentials following capsaicin-induced heat hyperalgesia. ${ }^{55}$ It is possible that capsaicin causes a decrease in the A-delta-fibre threshold giving rise to heat allodynia. ${ }^{55}$ Therefore, the ongoing pain and discharges of the sensitised nociceptors following capsaicin sensitisation depend on skin surface temperature: mild cooling of skin results in reduction of the burning pain sensation. ${ }^{55}$ This is why Lee et $\mathrm{al}^{12}$ suggested that during the decontamination process, allowing fresh air to circulate or even fanning the exposed area could assist in recovery. Cool water soothes the burning sensation while hot water increases it.

\section{Pharmacological use}

While our review focuses on OC spray, the most active ingredient capsaicin can be used therapeutically at an appropriate dilution. Prolonged topical application of capsaicin has been shown to induce a localised reversible loss of $>60 \%$ of nociceptive nerve fibre terminals in the epidermis and dermis ${ }^{56}$ and attenuate heat pain sensitivity (defunctionalisation 


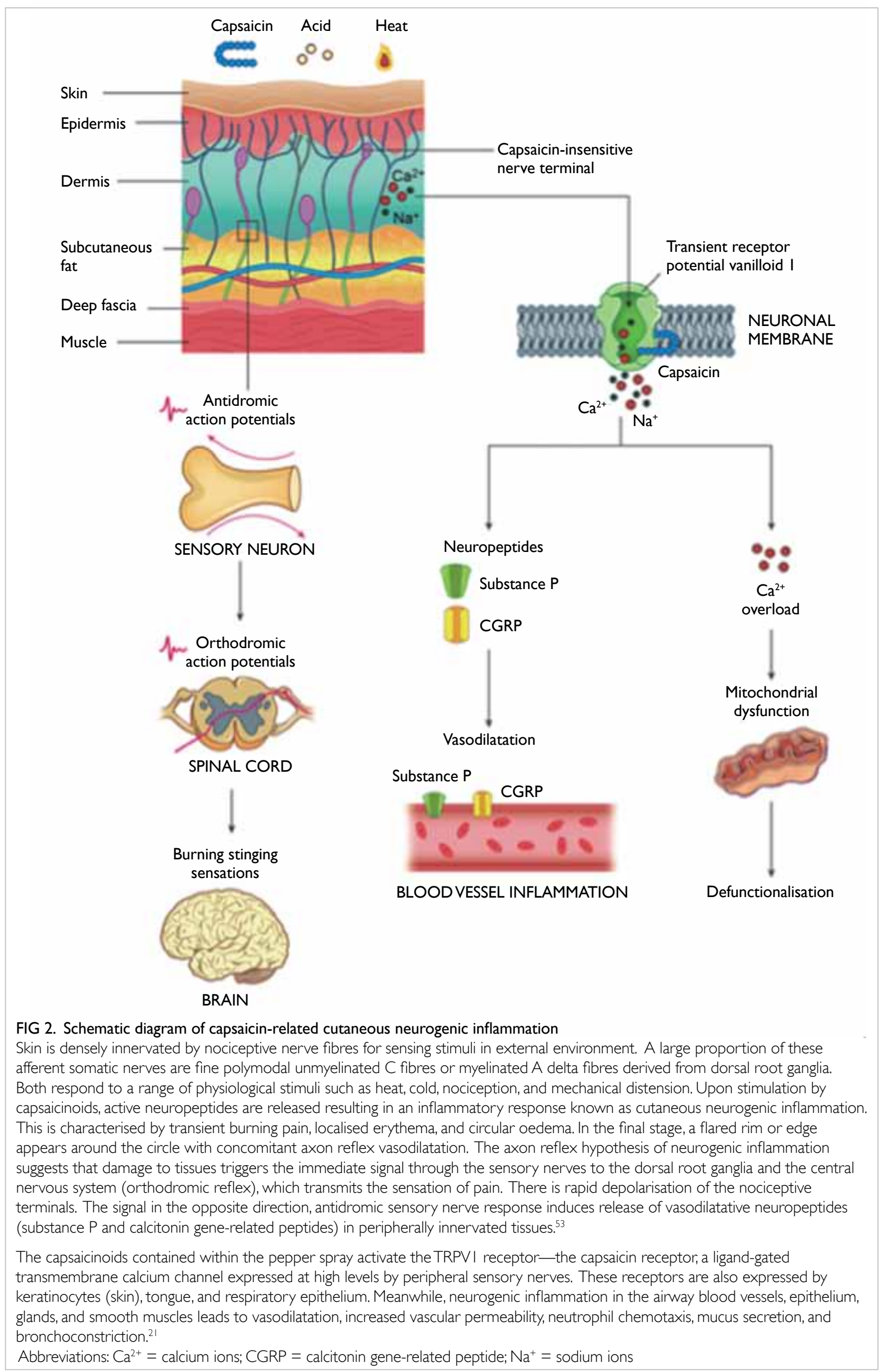


of TRPV1-expressing nociceptive fibres), resulting in relief in peripheral neuropathic pain syndromes. ${ }^{57}$

\section{Limitations}

There are limited large-scale case studies in the English literature of the clinicopathological effects of OC spray exposure. In some case series, data were reviewed retrospectively (from poison control centre registries) and may not have been collected using a standardised format, including exposure circumstances, thus some data might be missing. There was little information about the exact method, effectiveness, and precise timing of decontamination procedures or other interventions. Data on the concentration and especially SHU of OC spray, which could affect the strength and efficacy of spray to produce injury, were largely lacking, including particle size of OC spray and dose administered. The circumstances of exposure (riot control, crowd control, police cadet training, or domestic) and the scale of canister (distance of spray jet) would have affected the severity of clinicopathological effects of $\mathrm{OC}$ spray but were not recorded in detail. As most studies were observational or retrospective, a definite causal relationship between exposure and symptoms could not be drawn. There are likely variables and confounders present. In some studies, the reporting of symptoms was largely voluntary and thus likely to be biased. Most studies did not address chronic toxicity or residual disability in people exposed to OC spray.

\section{Conclusion}

Based on our review, OC spray appears to be an effective incapacitating riot-control agent. Significant adverse clinical effects or life-threatening conditions are not anticipated in the majority of exposures and death caused by OC spray exposure is unlikely. Dermatological and ophthalmic effects are commonly seen after exposure to OC spray in humans due to neurogenic inflammation. Careful early decontamination can minimise the irritant effects. Victims should be monitored for any evidence of serious adverse effects, with prompt medical intervention for any life-threatening symptoms. Large prospective cohort studies or casecontrol studies would strengthen the ability to infer a causal relationship between pepper spray exposure and health outcome.

\section{References}

1. Reilly CA, Crouch DJ, Yost GS. Quantitative analysis of capsaicinoids in fresh peppers, oleoresin capsicum and pepper spray products. J Forensic Sci 2001;46:502-9.

2. Reilly CA, Crouch DJ, Yost GS, Fatah AA. Determination of capsaicin, dihydrocapsaicin, and nonivamide in selfdefense weapons by liquid chromatography-mass spectrometry and liquid chromatography-tandem mass spectrometry. J Chromatogr A 2001;912:259-67.

3. Cordell GA, Araujo OE. Capsaicin: identification, nomenclature, and pharmacotherapy. Ann Pharmacother 1993;27:330-6.

4. Kearney T, Hiatt P, Birdsall E, Smollin C. Pepper spray injury severity: ten-year case experience of a poison control system. Prehosp Emerg Care 2014;18:381-6.

5. Watson WA, Stremel KR, Westdorp EJ. Oleoresin capsicum (Cap-Stun) toxicity from aerosol exposure. Ann Pharmacother 1996;30:733-5.

6. Stopford W. Occupational exposures to riot control agents. In: Olajos EJ, Stopford W, editors. Riot control agents. Issues in toxicology, safety and health. New York: CRC Press; 2004: 277.

7. Forrester MB, Stanley SK. The epidemiology of pepper spray exposures reported in Texas in 1998-2002. Vet Hum Toxicol 2003;45:327-30.

8. Zollman TM, Bragg RM, Harrison DA. Clinical effects of oleoresin capsicum (pepper spray) on the human cornea and conjunctiva. Ophthalmology 2000;107:2186-9.

9. Gerber S, Frueh BE, Tappeiner C. Conjunctival proliferation after a mild pepper spray injury in a young child. Cornea 2011;30:1042-4.

10. Brown L, Takeuchi D, Challoner K. Corneal abrasions associated with pepper spray exposure. Am J Emerg Med 2000;18:271-2.

11. Vesaluoma M, Müller L, Gallar J, et al. Effects of oleoresin capsicum pepper spray on human corneal morphology and sensitivity. Invest Ophthalmol Vis Sci 2000;41:2138-47.

12. Lee RJ, Yolton RL, Yolton DP, Schnider C, Janin ML. Personal defense sprays: Effects and management of exposure. J Am Optom Assoc 1996;67:548-60.

13. Oh JJ, Yong R, Ponampalam R, Anantharman V, Lim SH. Mass casualty incident involving pepper spray exposure: impact on the emergency department and management of casualties. Hong Kong J Emerg Med 2010;17:325-9.

14. Brvar M. Pepper spray (capsaicin) exposure: decontamination with amphoteric, chelating and hypertonic solution [abstract]. Clin Toxicol 2013;51:314.

15. Holopainen JM, Moilanen JA, Hack T, Tervo TM. Toxic carriers in pepper sprays may cause corneal erosion. Toxicol Appl Pharmacol 2003;186:155-62.

16. Kniestedt C, Fleischhauer J, Stürmer J, Thiel MA. Pepper spray injuries of the anterior segment of the eye [in German]. Klin Monbl Augenheilkd 2005;222:267-70.

17. Shimada M, Young C, Tanen DA. Corneal ulcer associated with pepper spray exposure during military training. J Emerg Med 2012;43:e149.

18. Das S, Chohan A, Snibson GR, Taylor HR. Capsicum spray injury of the eye. Int Ophthalmol 2005;26:171-3.

19. Busker RM, van Helden HP. Toxicologic evaluation of pepper spray as a possible weapon for the Dutch police force: risk assessment and efficacy. Am J Forensic Med Pathol 1998;19:309-16.

20. Broadstock $M$. What is the safety of 'pepper spray' use by law enforcement or mental health service staff? New Zealand Health Technology Assessment Tech Brief Series. Available from: http://nzhta.chmeds.ac.nz/publications/ pepper_spray.pdf. Accessed Oct 2015.

21. Smith CG, Stopford W. Health hazards of pepper spray. Available from: http://duketox.mc.duke.edu/pepper\%20 spray.pdf. Accessed 1 Dec 2014. 
22. Rasier R, Kukner AS, Sengul EA, Yalcin NG, Temizsoylu O, Bahcecioglu HO. The decrease in aqueous tear production associated with pepper spray. Curr Eye Res 2015;40:429-33.

23. Epstein RJ, Majmudar PA. Pepper spray in the eye. Ophthalmology 2001;108:1712-3.

24. Geppetti P, Fusco BM, Marabini S, Maggi CA, Fanciullacci $M$, Sicuteri F. Secretion, pain and sneezing induced by the application of capsaicin to the nasal mucosa in man. $\mathrm{Br} \mathrm{J}$ Pharmacol 1988;93:509-14.

25. Chan TC, Vilke GM, Clausen J, et al. The effect of oleoresin capsicum "pepper" spray inhalation on respiratory function. J Forensic Sci 2002;47:299-304.

26. Winograd HL. Acute croup in an older child. An unusual toxic origin. Clin Pediatr (Phila) 1977;16:884-7.

27. Billmire DF, Vinocur C, Ginda $M$, et al. Pepper-sprayinduced respiratory failure treated with extracorporeal membrane oxygenation. Pediatrics 1996;98:961-3.

28. Smith J, Greaves I. The use of chemical incapacitant sprays: a review. J Trauma 2002;52:595-600.

29. O'Halloran RL, Frank JG. Asphyxial death during prone restraint revisited: a report of 21 cases. Am J Forensic Med Pathol 2000;21:39-52.

30. USA: Excessive and lethal force? Amnesty International's concerns about deaths and ill-treatment involving police use of Tasers. Available from: http://www.amnestyusa.org/ node/55449? page=72. Accessed 7 Dec 2014 .

31. Steffee CH, Lantz PE, Flannagan LM, Thompson RL, Jason DR. Oleoresin capsicum (pepper) spray and "in-custody deaths." Am J Forensic Med Pathol 1995;16:185-92.

32. Granfield J, Onnen J, Petty CS. Pepper spray and incustody deaths: international association of chiefs of police executive brief. RCMP Gazette 1994;56:12-7.

33. Pollanen MS, Chiasson DA, Cairns JT, Young JG. Unexpected death related to restraint for excited delirium: a retrospective study of deaths in police custody and in the community. CMAJ 1998;158:1603-7.

34. Lee DC, Ryan JR. Magnesium-aluminum hydroxide suspension for the treatment of dermal capsaicin exposures. Acad Emerg Med 2003;10:688-90.

35. Jones L, Tandberg D, Troutman WG. A controlled evaluation for household treatments for "chile burns". Vet Hum Toxicol 1986;28:486.

36. Vogl TP. Treatment of Hunan hand. $N$ Engl J Med 1982;306:178.

37. Barry JD, Hennessy R, McManus JG Jr. A randomized controlled trial comparing treatment regimens for acute pain for topical oleoresin capsaicin (pepper spray) exposure in adult volunteers. Prehosp Emerg Care 2008;12:432-7.

38. Schep LJ, Slaughter RJ, McBride DI. Riot control agents: the tear gases CN, CS and OC-a medical review. J R Army Med Corps 2015;161:94-9.

39. Adkins LD. Oleoresin capsicum: an analysis of the implementation of pepper spray into the law enforcement use of force continuum in a selected police department. Available from: http://dc.etsu.edu/etd/779. Accessed 23 Jan 2015.

40. National Institute of Justice. Oleoresin capsicum: pepper spray as a force alternative. Available from: https://www. ncjrs.gov/pdffiles1/nij/grants/181655.pdf. Accessed 23 Jan 2015.

41. Tominack RL, Spyker DA. Capsicum and capsaicin-a review: case report of the use of hot peppers in child abuse. J Toxicol Clin Toxicol 1987;25:591-601.

42. Monsereenusorn Y, Kongsamut S, Pezalla PD. Capsaicin-a literature survey. Crit Rev Toxicol 1982;10:321-39.

43. Hilmas CJ, Poole MJ, Katos AM, Williams PT. Chapter 12: Riot control agents. In: Handbook of toxicology of chemical warfare agents. Available from: http://www.dtic. mil/dtic/tr/fulltext/u2/a539686.pdf. Accessed Oct 2015.

44. Weinberg RB. Hunan hand. N Engl J Med 1981;305:1020.

45. Greer JM, Rosen T, Tschen JA. Sweet's syndrome with an exogenous cause. Cutis 1993;51:112-4.

46. Blanc P, Liu D, Juarez C, Boushey HA. Cough in hot pepper workers. Chest 1991;99:27-32.

47. Kasting GB. Kinetics of finite dose absorption through skin 1. Vanillylnonanamide. J Pharm Sci 2001;90:202-12.

48. Durnford JM. Chapter 10: Genetic toxicity of riot control agents. In: Olajos EJ, Stopford W, editors. Riot control agents. Issues in toxicology, safety and health. New York: CRC Press; 2004: 183-200.

49. The American Civil Liberties Union of Southern California. Pepper spray update: more fatalities, more questions; 1995 Jun. Available from: https://www.aclusocal.org/issues/ police-practices/pepper-spray/. Accessed 19 Nov 2014.

50. International Association of Chiefs of Police. Pepper spray evaluation project; 1995 Jun 22. Available from: http:// www.theiacp.org/portals/0/pdfs/IntroPepperSpray.pdf. Accessed 19 Nov 2014.

51. Christensen RG, Frank DE. Preliminary investigation of oleoresin capsicum. National Institute of Justice Report 100-95, Gaithersburg, MD: National Institute of Standards and Technology; 1995.

52. Pershing LK, Corlett JL, Nelson JL. Comparison of dermatopharmacokinetic vs. clinical efficacy methods for bioequivalence assessment of miconazole nitrate vaginal cream, 2\% in humans. Pharm Res 2002;19:270-7.

53. Caterina MJ, Schumacher MA, Tominaga M, Rosen TA, Levine JD, Julius D. The capsaicin receptor: a heat-activated ion channel in the pain pathway. Nature 1997;389:816-24.

54. LaMotte RH, Shain CN, Simone DA, Tsai EF. Neurogenic hyperalgesia: psychophysical studies of underlying mechanisms. J Neurophysiol 1991;66:190-211.

55. Madsen CS, Johnsen B, Fuglsang-Frederiksen A, Jensen TS, Finnerup NB. Increased contact heat pain and shortened latencies of contact heat evoked potentials following capsaicin-induced heat hyperalgesia. Clin Neurophysiol 2012;123:1429-36.

56. Kennedy WR, Vanhove GF, Lu SP, et al. A randomized, controlled, open-label study of the long-term effects of NGX-4010, a high-concentration capsaicin patch, on epidermal nerve fiber density and sensory function in healthy volunteers. J Pain 2010;11:579-87.

57. Anand P, Bley K. Topical capsaicin for pain management: therapeutic potential and mechanisms of action of the new high-concentration capsaicin $8 \%$ patch. Br J Anaesth 2011;107:490-502. 